\title{
Municipal Audit Outcomes: Toward Collective Management and Intervention Strategies in the Free State Province
}

\author{
Beaula M. Kruger, Cornelis J. Van Rooyen \\ Free State Provincial Legislature, Free State, South Africa
}

\begin{abstract}
The Local Government Municipal Finance Management Act No. 56 of 2003 provided guidelines/framework for sound and sustainable management of the financial affairs of municipalities and other institutions in local sphere of government. In addition, the Free State Provincial Legislature Standing Committee of Public Accounts provided oversight over the Executive Committee and Local Government on public spending, however, there remained to be financial challenges persisting in South African municipalities. In response to this, Operation Clean Audit was launched in 2009 in the South African Parliament and they expected 100\% clean audit status from local governments by 2014. Despite their expectation, 2014 was a year where the Free State government municipalities faced several challenges. The definition of a clean audit report, according to the Auditor General, is unqualified audit outcome without findings on compliance and performance information. Departing from this definition, no municipality or municipal entity in the Free State province achieved a clean audit opinion during the 2013/2014 financial year.
\end{abstract}

Keywords: public financial management, oversight, accountability, good governance

\section{Municipal Financial Management Act (MFMA)}

The Municipal Financial Management Act (MFMA) of No. 56 of 2003 is applicable to all municipalities, all municipal entities, and national and provincial organs of state to the extent of their financial dealings with municipalities. The objective of the act is to ensure sound and sustainable management of the fiscal and financial affairs of municipalities and municipal entities by establishing norms, standards, and other requirements to ensure:

(1) That municipalities and municipal entities are transparent, accountable, and conduct appropriate lines of responsibility in their fiscal and financial affairs;

(2) The management of their revenues, expenditures, assets, liabilities, and the conduct of their financial transactions;

Corresponding author: Beaula M. Kruger, BA in International Relations and Postgraduate Diploma in Governance and Political Transformation from the University of the Free State (UFS), currently employed as the ANC (African National Congress) Caucus Senior Researcher in the Office of the Chief Whip in the Free State Legislature, and in addition serves as the Deputy Coordinator of the ANC Free State Provincial Elections Research Team (PERT), Free State Provincial Legislature, South Africa; research fields: governance and political transformation, public administration, elections management, higher education, legislative rules and orders, youth development and community engagement.

Cornelis J. Van Rooyen, BA in Public Administration from the University of the Free State (UFS), Member of the Free State Provincial Legislature (MPL), Chief Whip of Legislature and Chairperson for Public Accounts and Finance Committee, Free State Provincial Legislature, South Africa; research fields: public finances, public accounts, division of revenue, legislation rules and orders and political communication. 
(3) Budgetary and financial planning processes and the co-ordination of those processes with the processes of organs of state in other spheres of government;

(4) Borrowing and handling of financial problems which may occur in municipalities;

(5) Supply chain management and all other financial management (Republic of South Africa, 2003, p. 23).

Municipal finances not only involve processes, but they are also regulated by the MFMA which includes: budgetary processes, capital planning, consumer debt, revenue management, procurement, and most importantly financial reporting and auditing. The purpose of financial auditing is to detect possible problems that may compromise the system, and therefore audit reports play a vital role:

(1) By ensuring that the financial statements are not subjected to misstatements;

(2) By reporting on the credibility and reliability of the information;

(3) By reporting on material non-compliance with key legislation;

(4) By identifying key internal control deficiencies (Mtwesi, 2015).

However despite the guidelines/frameworks provided in the MFMA, the financial health of the province faced several challenges relating to financial management in municipalities. Local municipalities in the Free State during the 2013/2014 financial year faced several challenges related to: slow response by management, cash flow constraints, unauthorised and irregular expenditure, supply management, skills shortage, information technology, and security management. The biggest challenge however in the Free State is to ensure that government builds a public service which is characterised by transparent finance and performance reporting (Auditor-General, 2015, pp. 6-7). Here, the role and functions of the provincial Public Accounts Committee (PAC) play a vital role as a mechanism through which the Free State Provincial Legislature exercises control over the expenditure of public money (Provincial Public Accounts Committee's method of work, 2015, p. 1). The Association of Public Accounts Committees (APAC) plays a crucial role in ensuring that PAC members and support staff are prepared to effectively and efficiently perform their oversight and accountable functions. It is therefore, institutions such as APAC, Auditor-General, National Treasury, and the South African Legislative Sector that are continuously capacitating PAC members to execute their mandate (Makhado, Masehela, \& Mokhari, 2012, pp. 1-2). The main function of the committee is to examine the financial issues/concerns raised by the Auditor-General. The Public Accounts Committee assesses the report, its criticism, and recommendations made by the Auditor-General (Provincial Public Accounts Committee's method of work, 2015, pp. 1-3). Therefore, the PAC enhances oversight and accountability of public funds by promoting effectiveness, efficiency, and economics (EEEs) of public resources allocated. The effectiveness and efficiency of the PAC members and their work is measured on the basis of the committee's ability to provide oversight and accountability. The concept of oversight is defined by the National Parliament of South Africa in 2009, outlining the functions as:

(1) Protect the rights and freedom of citizens, while holding government departments and public entities accountable for use of "taxpayers' money";

(2) Improve on the accomplishment of government departments and public entities in relation to their Annual Performance Plan (APP) and Strategic Plan, while improving on the efficiency and effectiveness of government operations;

(3) Reinforcement of transparency and good governance.

The National Parliament of South Africa further provides a working definition and functions of accountability. Accountability is understood as the ability to "give an account" or to "account for" the spending 
of public funds. The functions of accountability include:

(1) Effect and strengthen democratic control while enhancing the integrity of public governance;

(2) To improve service delivery performances and review the performance of government;

(3) The implementation tools of accountability involve conducting budget votes (direct tool of accountability), and public hearings (the power to summon the executive bodies to account for their decisions and actions taken) (Makhado et al., 2012, pp. 4-5).

What strategies have the South African national government and the Free State government employed to address these issues?

\section{Overview of National and Provincial Government Initiatives}

The South African Constitution Act 108 of 1996, Section 151 (1)-(4) on Local Government, stipulates that local sphere of government consists of municipalities which have executive and legislature authority that is vested in the Municipal Council. Furthermore, municipalities have the right to govern using its own initiative, however, the local government affairs are subject to both national and provincial legislation provided by the constitution. Section 152 (1) stipulates the objectives of local government which are as follows:

(1) Provide democratic and accountable government for local communities;

(2) Ensure the provision of services to communities in a sustainable manner;

(3) Promote social and economic development;

(4) Promote a safe and healthy environment;

(5) Encourage the involvement of communities and community organisations in the matters of local government (Auditor-General, 2015, p. 10).

Furthermore, Section 152 (2) of the constitution stipulates that: "A municipality must strive, within its financial and administrative capacity, to achieve the objects set out in subsection (1)" [Republic of South Africa (RSA), 1996, p. 1331]. In efforts to align with the constitutional provisions and improve on audit outcome, the "Back to Basics Strategy" was launched in the Free State in October 2014. The Free State government had aligned its Municipal Support Programme with the "Back to Basics Strategy" which focuses on: prioritising people and their concerns, creating decent living conditions, demonstrating good governance, certifying sound financial management, and the construction and maintenance of sound institutional and administrative capabilities. In the same year, the objectives set out in the Operation Clean Audit (OPCA) 2014, were expected to have been achieved by the end of 2014. OPCA 2014 was launched on September 22, 2009 based on the findings of the South African government study into issues relating to service delivery, leadership, financial management, and governance (Auditor-General, 2015, p. 11). The Department of Cooperative Governance and Traditional Affairs (COGTA) has made several attempts to improve the audit outcomes of local municipalities. However, the Local Government Turn Around Strategy (LGTAS) was disbanded in 2011 due to stagnation for a period of 18 months. Improvements have been evident following the appointment of a new minister, the LGTAS has improved in terms of directing their attention to the 108 municipalities. The LGTAS has identified key areas to ensure the improvements of audit outcomes of municipalities, and these include: enhancing good governance, promoting sound financial management, accelerating service delivery, fighting corruption, and facilitating sustainable infrastructure development (Chaane, 2012). In efforts toward supporting COGTA's OPCA 2014, the Auditor General South Africa (AGSA) strengthened their interactions with political and administrative leadership on their outcomes in municipalities. The AGSA operates on a constitutional mandate, 
and as the Supreme Audit Institution (SAI) of South Africa, they are committed to ensure oversight, accountability, and governance in the public sector through auditing which would ultimately result in the South African public confidence. In addition, the AGSA has further committed itself to being a critical supporter of the Free State government's back-to-basics initiative (Auditor-General, 2015, p. 11).

\section{Toward Collective Management and Intervention Strategies}

Despite these initiatives, the Free State government municipalities have received criticism regarding their continuous financial difficulties over the years. The Free State 2013/2014 general report on the audit outcomes of local government indicated that no municipality or municipal entity achieved a clean audit report (Auditor-General, 2015, pp. 6-7). The general report on the local government audit outcomes of the Free State MFMA 2013/2014, further indicates that there is a lack of improvement with regards to day-to-day operations, lack of skilled employees and various key vacancies (including municipal manager, chief financial officer, head of supply chain management), submissions of poor financial information, little improvement in the information technology controls, and concern remaining with the level of unauthorised, irregular, fruitless, and wasteful expenditure in the Free State municipalities. However, progress has been made; the 2013/2014 municipal audit outcomes indicate a net improvement in four audit outcomes from 2012/2013. Six auditees improved and two regressed. These improvements were realised through audit adjustments and the use of consultants. The general report on local government audit outcomes of the Free State for 2013/2014 indicated that 38\% of the audit outcomes were modified (unqualified with findings on compliance or performance report). Modified outcomes representing $62 \%$ remained a concern because it directly affected budgets by municipalities. Table 1 indicates audit outcomes of 2013/2014: the movements, improvements, and regression of municipalities in the Free State.

Table 1

Free State Audit Outcomes of 2013/2014

\begin{tabular}{|l|l|l|l|}
\hline Audit outcomes & Improved (6) & Unchanged (19) & Regressed (2) \\
\hline Unqualified with findings (12) & $\begin{array}{l}\text { Mangaung metro } \\
\text { Metsimaholo } \\
\text { Setsoto } \\
\text { Tokologo } \\
\text { Centlec }\end{array}$ & $\begin{array}{l}\text { Lejweleputswa district } \\
\text { Thabo Mofutsanyana district, } \\
\text { DihlabengNketoana, Twelopele } \\
\text { Maluti-a-Phofung water } \\
\text { Lejwaleputswa } \\
\text { Development agency }\end{array}$ & $\begin{array}{l}\text { Xhariep district } \\
\text { Kopanong } \\
\text { Masilonyana } \\
\text { Mohokare }\end{array}$ \\
\hline Qualified with findings (6) & Naledi & $\begin{array}{l}\text { Mafube, Maluti-a-Phofung, } \\
\text { Mantsopa } \\
\text { Matjhabeng, Moqhaka, Nala, } \\
\text { Ngwathe, Phumelela }\end{array}$ & Letsemeng \\
\hline Disclaimer with findings (9) & & Dabi district \\
\hline
\end{tabular}

Note. Colour of name indicates audit opinion from which the auditee has moved; adapted from Auditor-General (2015, p. 26).

The 2013/2014 audit outcomes in Table 1 indicated the improvements, unchanged status and regressions by municipalities. On improvements, five auditees improved from qualified to unqualified audit opinions with findings, and therefore only 12 auditees had unqualified audit outcomes. Furthermore, majority of the auditees improved due to enhanced oversight and responding timeously to financial issues. Naledi has also improved from a disclaimer of opinion to a qualified audit opinion. These improvements are clear indications of 
improved leadership, accountability, and greater levels of discipline. Regarding unchanged opinions, 19 auditees did not improve on their audit outcomes, while seven auditees maintained an unqualified audit opinion with findings. These findings are a result of lack of pivotal and rigorous leadership, neglect for good governance principles, and lack of enhancement of the basic values governing public administration. Finally, on regression, two municipalities have regressed in their audit outcomes, despite the Free State government's goal of moving toward sound financial management and accountability. The Auditor-General is of the opinion that the regression of two municipalities is a result of lack of implementing recommendations made in the previous year.

The Free State government has taken a hands-on approach through improved coordination to focus on these target areas and developed support programmes for the municipality. In addition, a proactive approach was also employed by both political leadership and management from district and local municipalities in terms of internal control environment (respecting and implementing good governance principles). Furthermore, the support shown by the Auditor General in the Free State also contributed toward the enhancement of accountability, transparency, and interpreting legislation into everyday operations in these municipalities (Rockman, 2016, p. 7). As a result, at local government level, the Free State government with its collective management and intervention programmes assisted provincial municipal audit outcomes. The coordination and support programmes were implemented by the Department of COGTA, Provincial Treasury, South African Local Government Association (SALGA), and National Treasury, efforts resulted in the following:

(1) The Thabo Mofutsanya District Municipality obtained the first clean audit by a Free State municipality;

(2) Municipalities that were improved from "qualified" to "unqualified" audit opinions were achieved by the Mohokare Local Municipality and Fezile Dabi District Municipality;

(3) Municipalities that were improved from a "disclaimer" to "unqualified" audit opinions included: Moqhaka, Letsemeng, and Mantsopa local municipalities;

(4) In 2013/2014, nine municipalities received disclaimer opinions, this has decreased to only three in 2014/2015.

In the 2016 media release by the Auditor-General of South Africa, the Free State municipalities amongst other provinces, received appraisal for showing that they are moving towards the right direction especially noting the improvements made by Thabo Mofutsanyana District Municipality. However, the Auditor General advised that "leadership in the provinces should place more emphasis on the benefits of good governance at all municipalities" (Auditor-General, 2016, p. 4). Koma (2010, p. 116) endorsed the advice by the Auditor-General and further added that solid, lucid, and transformative leadership is required to ensure results on service delivery.

\section{What Did the Free State Provincial Government Do Differently}

The Free State government established a Provincial Audit Intervention Committee that directly addressed the broader coordination of the provincial and municipal audit processes. The Provincial Audit Intervention Committee intervened in municipalities that were not progressing. Furthermore, constant facilitation of communication with key role-players was ensured to address transversal issues and technical disputes. The role of the Provincial Audit Intervention Committee has proven to be key in the improvements of the 2014/2015 audit outcomes. The Intervention Committee has assisted in ensuring enhanced efficient and effective audit processes in the Free State province. Other programmes facilitated in the improvements of municipal audit 
outcomes are the Fraud Awareness Week which provides informative and educational sessions throughout the province. In partnership with different stakeholders, the province now participates in the International Fraud Awareness Week activities. Twenty (20) public servants from both provincial and local government sector attended the Certified Fraud Examiners training, in addition to all provincial government departments that have developed and successfully implemented a Fraud Prevention and Response Plan. In response to Free State municipalities decline in revenue collection due to high unemployment rate and economic challenges, Provincial Treasury, COGTA, SALGA, Department of Energy and Eskom have established a Steering Committee to review all payment plans submitted to Eskom. This Steering Committee has assisted municipalities with developing payment plans and turnaround strategies. In addition, the Free State local government is also considering an alternative funding model for electricity supply and the distribution of electricity in identified municipalities, which is currently being developed (Rockman, 2016, pp. 7-8).

The improvement of the audit outcomes in the Free State municipalities is not an isolated achievement. The Auditor-General has announced that there are considerable improvements in South Africa's local government audit outcomes for the 2014/2015 financial year. The number of unqualified audit opinions with no findings in South Africa has increased from 13 to 54 and 18 additional municipal entities also achieved clean audit outcomes, making a total of 72 for the 2014/2015 financial year (Auditor-General, 2016, p. 1). It is therefore clear that local governments in South Africa are employing financial management disciplines, improving oversight structures and decisive leadership. South African municipalities should have strategic leaders with the skills and knowledge in order to achieve municipal strategic vision and objectives. Provincial governments and treasuries should be more strategic in their allocation of resources and should be more attentive to low-capacity municipalities (Koma, 2010, pp. 116-117).

\section{Conclusions}

The general report on the local government audit outcomes of the Free State 2013/2014 did not indicate any significant improvements since the previous year. Despite efforts made by the provincial government, challenges within these municipalities persisted. However, through the collective leadership approach and intervention strategies employed, the 2014/2015 audit outcomes already indicate an improvement in the municipalities. The establishments of the Provincial Audit Intervention Committee, Fraud Awareness Week, and the Steering Committee are additional programmes developed by the Free State government. These programmes are aligned with legislation such as the MFMA and the Back-to-Basic plan. The Provincial Committee of Public Accounts now has to continue enhancing their oversight by monitoring the public funds spent by municipalities in the Free State province. The interventions by the Free State government have proven to be beneficial in order to ensure efficiency and effectiveness as well as accountability of all stakeholders involved. Despite the challenges faced by the municipalities in the Free State, there is a clear indication that in the province, financial management of municipalities is moving toward a positive and improved direction.

\section{References}

Auditor-General. (2015). General report on the local government audit outcomes of the Free State. Pretoria: Government Printers. Auditor-General. (2016). Media release. Retrieved from https://www.agsa.co.za/Portals/0/MFMA\%202014-15/Section\%201-9\% 20MFMA\%202014-2015/FINAL\%20MEDIA\%20RELEASE\%20(MFMA\%202016)\%20FN.pdf

Chaane, T. (2012). Operation clean audit by 2014: Department cooperative governance progress report. Parliamentary Monitoring Group. Retrieved from https://pmg.org.za/committee-meeting/15024/ 
Koma, S. B. (2010). The state of local government in South Africa: Issues, trends and options. Journal of Public Administration, 45(1), 111-120.

Lotriet, D. (2015). No clean audits for Free State municipalities. Mail \& Guardian. Retrieved from http://mg.co.za/article/ 2015-06-10-no-clean-audits-for-free-state-municipalities

Makhado, R. A., Masehela, K. L., \& Mokhari, R. W. (2012). Effectiveness and efficiency of Public Accounts Committees (PACs) in enhancing oversight and accountability in the public sector. Proceedings from the 2012 SALSA Development Seminar. October 2-5, East London, Eastern Cape, South Africa.

Mtwesi, A. (2015). Fundamentals of municipal finances. Helen Suzman Foundation. Retrieved from http://hsf.org.za/resourcecentre/hsf-briefs/fundamentals-of-municipal-finances

Provincial Public Accounts Committee's method of work. (2015). Office of the Chief Whip, Free State Legislature.

Republic of South Africa (RSA). (1996). Constitution of the Republic of South Africa Act (Act 108 of 1996). Pretoria: Government Printers.

Republic of South Africa. (2003). Local government: Municipal financial management act. Retrieved from https://www. westerncape.gov.za/Text/2004/8/mfma.pdf

Rockman, E. (2016). Department of Treasury budget vote 2016/2017. Free State government. Bloemfontein: Government Printers. 